Testy Psychologiczne w Praktyce i Badaniach, 2019, Numer specjalny, 2, 20-40, ISSN: 24499072

BARTOSZ ZALEWSKI*

Uniwersytet SWPS, Ogólnopolska Sekcja Diagnozy Psychologicznej Polskiego Towarzystwa Psychologicznego

HANNA PINKOWSKA-ZIELIŃSKA

Ośrodek Terapeutyczno-Szkoleniowy Kontrakt, Sekcja Naukowa Terapii Rodzin Polskiego

Towarzystwa Psychiatrycznego

MARIA ZAPOLSKA-DOWNAR

Warszawski Instytut Psychoterapii

\title{
Diagnoza par i rodzin do psychoterapii - omówienie dokumentu
}

\begin{abstract}
W tekście opisano proces tworzenia dokumentu opisującego wskazówki dla diagnozowania par i rodzin do psychoterapii, wynikające ze standardów ogólnych, omówiono strukturę dokumentu i zawartość poszczególnych części oraz odniesiono je do Kodeksu Etycznego psychoterapeutów (w jego części dotyczącej terapii par i rodzin).
\end{abstract}

The text describes how a document describing guidelines for diagnosing couples and families for psychotherapy, resulting from general standards, was created, the structure and content of the document was discussed and its reference to the Code of Ethics of Psychotherapists (in its part concerning the therapy of couples and families).

Dokument „Wskazówki realizacji standardów ogólnych prowadzenia procesu diagnostycznego w diagnostyce par i rodzin do psychoterapii” został uchwalony 19 stycznia 2019 roku przez Walne Zebranie Ogólnopolskiej Sekcji Diagnozy Psychologicznej PTP oraz 5 lipca 2019 roku przez Zarząd Sekcji Naukowej Terapii Rodzin Polskiego Towarzystwa Psychiatrycznego . Jest on uszczegółowieniem dokumentu „Standardy prowadzenia procesu diagnostycznego" uchwalonego 21 czerwca 2014 roku i znowelizowanego w 2018 roku przez Sekcję Diagnozy PTP.

Podobnie jak dla Standardów ogólnych celem powstania dokumentu jest wsparcie psychologów w rozwiązywaniu różnorodnych dylematów w pracy diagnostycznej, budowaniu pozycji zawodowej we własnym środowisku pracy oraz tworzeniu programów szkoleń diagnostycznych w zakresie par i rodzin. Wskazówki są odpowiedzią na dynamiczne zmiany zachodzące na rynku usług psychoterapeutycznych kierowanych do par i rodzin: zwiększenia ilości terapeutów tej specjalizacji oraz pojawiających się odrębnych usług, polegających na przygotowywaniu samodzielnej i oddzielnej od psychoterapii całościowej

* Adres do korespondencji: Bartosz Zalewski, Katedra Diagnozy Psychologicznej Wydział Psychologii SWPS w Warszawie bzalewsk@swps.edu.pl 
diagnozy pary lub rodzin. Konsultowanie par i rodzin jest szczególnie skomplikowane z powodu diagnozowania kilku osób jednocześnie z jednej strony, oraz dominujących w Polsce i na świecie konstrukcjonistycznych modeli terapii rodzin, generalnie kwestionujących możliwości budowania diagnozy z drugiej (por. Chrząstowski i de Barbaro, 2011). Wokół konsultowania par i rodzin może zatem powstawać zamieszanie dotyczące celów oraz sposobów prowadzenia procesu diagnostycznego. Szczególnie ważne wydaje się w tym kontekście uporządkowanie zasad prowadzenia tego procesu oraz wskazania najlepszych praktyk postępowania diagnostycznego.

\section{Powstawanie wskazówek}

Pierwszą wersję wskazówek opracował, powołany w grudniu 2015 roku Zespół ds. Diagnozowania Par i Rodzin, działający w Ogólnopolskiej Sekcji Diagnozy Psychologicznej Polskiego Towarzystwa Psychologicznego. Koordynatorem prac został Bartosz Zalewski, a członkami zespołu byli: Hanna Pinkowska-Zielińska, Bartosz Szymczyk, Joanna Krasuska i Maria Zapolska-Downar. Zespół spotykał się regularnie przez około pół roku. Najważniejsze punkty wskazówek zostały następnie poddane dyskusji w formie warsztatu zorganizowanego podczas tzw. Trójkonferencji w 2016 roku (Konferencja Trzech Sekcji pt „Natura i kultura. Psychoterapia wobec fenomenu agresji we współczesnym świecie”, 21-23.10.2016 r., Warszawa) oraz podczas dyskusji zorganizowanej w trakcie Kongresu PTP w 2017 roku (36 Kongres Polskiego Towarzystwa Psychologicznego pt. „Psychologia dla zdrowia osoby i społeczeństwa”, 21-24.09.2017 r., Uniwersytet Gdański). Uzyskane w ten sposób opinie przedyskutowano w Zespole i wprowadzono zmiany do treści wskazówek.

Jednocześnie w 2017 roku nawiązano współpracę z Sekcją Naukową Terapii Rodzin Polskiego Towarzystwa Psychiatrycznego. Szczególnie duży wkład w treść dokumentu miał Szymon Chrząstowski, który z ramienia Zarządu Sekcji Terapii Rodzin PTP współpracował z zespołem tworzącym wskazówki. Tak przygotowany dokument poddano konsultacjom społecznym w grudniu 2018 roku za pomocą ankiety internetowej, w której każda wskazówka oceniana była pod kątem jej klarowności, wykonalności oraz zasadności, możliwe było także dodawanie własnych komentarzy. Prośbę o udział w konsultacjach rozesłano do członków obu Sekcji, a także rozdawano w formie ulotek w trakcie kolejnej edycji Trójkonferencji w 2018 roku w Warszawie. Niestety w konsultacjach wzięło udział jedynie osiem osób. Ze względu na długi czas przygotowywania dokumentu, zdecydowano się wprowadzić niewielkie korekty, postulowane przez uczestników konsultacji oraz sformułować końcowe brzmienie Wskazówek. Ostateczną treść dokumentu uchwaliły 
Zarządy obu Sekcji, odpowiednio 19 stycznia i 5 lipca 2019 roku. Zawiera on wszystkie standardy ogólne, a w miejsce rozwinięcia brzmienia standardu wpisane są odpowiednie wskazówki diagnozowania par i rodzin do psychoterapii.

\section{Standardy ogólne, Kodeks Etyczny a Wskazówki}

Standardy obejmują ogólny opis zasad postępowania psychologa podczas prowadzenia procesu diagnostycznego, zaś dokumenty zawierające wskazówki odnoszą je do konkretnych, specyficznych obszarów praktyki. Z założenia wskazówki powinny być niesprzeczne ze standardami ogólnymi. W opisywanym tu dokumencie używane jest określenie „wskazówki”, ponieważ ma ono mniej nakazowy charakter niż pojęcie „wytyczne”, co jest zgodne $\mathrm{z}$ duchem standardów, których celem jest edukowanie psychologów (oraz ich klientów) w zakresie dobrych praktyk, nie zaś penalizacja. Mają one zatem wskazywać rozwiązania zgodne z zasadami dobrej praktyki psychologicznej. Droga ta zakorzeniona jest w szerszym myśleniu o edukacyjnej roli standardów diagnozowania w Europie (GAP, Fernandez-Ballesteros i in, 2001) oraz Stanach Zjednoczonych (Krishnamurthy i in., 2004; por. Paluchowski i in, 2015; Paluchowski, 2010). Jednocześnie jest to myślenie odmienne od tego, które leży u źródeł kodeksów etycznych, gdzie oprócz wskazywania standardów optymalnego postępowania psychoterapeuty, opisane są także zasady ich dyscyplinowania.

Wytyczne, podobnie jak Standardy nie są dokumentem zamkniętym, skończonym, lecz powinny być systematycznie zmieniane, uzupełniane i modyfikowane (por. Paluchowski i in, 2015), tak aby odpowiadać na zmieniające się warunki praktyki psychoterapeutycznej oraz rozwój wiedzy psychologicznej. Wymagania zawarte w obu dokumentach powinny być stale podnoszone, tak aby stymulować rozwój dobrych praktyk. Ważnym rozróżnieniem pomiędzy dokumentami opisującymi Standardy oraz Wskazówki jest dookreślenie adresata dokumentu - od psychologa w Standardach, do psychoterapeuty we Wskazówkach. Nie każdy psychoterapeuta jest psychologiem, niemniej należy podkreślić, że podstawą działań psychoterapeuty są teorie psychoterapeutyczne, które z kolei oparte są na wiedzy psychologicznej.

Rok po zatwierdzeniu Standardów ogólnych opublikowano nowy Kodeks Etyczny Psychoterapeutów Polskiego Towarzystwa Psychiatrycznego, przyjęty w 2015 roku przez Sekcję Naukową Psychoterapii oraz Sekcję Naukową Terapii Rodzin (PTP, 2015). Po raz pierwszy w Kodeksie Etycznym pojawiły się zapisy odnoszące się do psychoterapii par i rodzin, opisane w części dziewiątej dokumentu. Zawarte tam zasady znajdują swoje odbicie 
we Wskazówkach, a jednocześnie oba dokumenty różnie opisują „rodzinę”: we Wskazówkach jest ona traktowana jako grupa osób, o których dobro należy dbać łącznie podczas sesji konsultacyjnych (co wynika z konstrukcji standardów, skupionych na jednostce), w Kodeksie natomiast rodzina traktowana jest jako odrębna całość. Poza częścią dziewiątą do par i rodzin stosują się także inne zasady etyczne, z których we Wskazówkach opisane są: wymagania dotyczące profesjonalnych kompetencji diagnosty (1.1), stałego superwizowania swojej pracy diagnostycznej $(1.7 ; 1.8)$, standardy prawne $(2.7 ; 2.8$ i $2.9 ; 5.5)$ czy relacje terapeuty z innymi profesjonalistami (1.4).

\section{Treść Wskazówek}

Omawiane tu Wskazówki odnoszą się do wszystkich części Standardów. W części pierwszej opisane są kwestie obecności członków rodziny podczas konsultacji oraz sytuacje szczególne odstąpienia od tej zasady, umieszczone w kontekście stosowanego podejścia psychoterapeutycznego. Ponadto wskazane są warunki pracy nad motywacją rodziny do uczestnictwa w procesie diagnostycznym, specyficzne kompetencje diagnosty do pracy z parami i rodzinami, specyfika budowania sojuszu diagnostycznego oraz kwestia dyskomfortu członków rodziny podczas konsultacji. Dyskomfort ten ma wiele źródeł i może być szczególnie duży, stąd opis jego wpływu na sposób planowania i przeprowadzania badań diagnostycznych, zawarty w części drugiej i trzeciej Wskazówek.

Część czwarta omawia strategie badawcze stosowane przy diagnozowaniu kilku osób jednocześnie, w tym problemy związane ze standaryzacją warunków badania w sytuacji wielości czynników wpływających na jego przebieg. Szczególnie wymagającym zadaniem jest jednoczesne diagnozowanie rodziny oraz pojedynczej osoby podczas tej samej konsultacji (np. rodziny oraz dziecka w tej rodzinie), co nastręcza wielu kłopotów metodologicznych i może obniżać zaufanie do wyników badań. Zaznaczona jest możliwość odsyłania poszczególnych osób do diagnostyki indywidualnej. Odrębnie podkreślone są zniekształcenia poznawcze występujące u diagnostów i wpływające na formułowanie wniosków diagnostycznych. Kształt konsultacji rodzinnych, wielość osób i czynników wpływających na ich przebieg, trudności metodologiczne oraz poziom skumulowanej siły emocji kilku osób naraz - wszystko to tworzy duże pole do upośledzania przez nie procesów poprawnego myślenia diagnostycznego (Chrząstowski, 2014). Zasady przekazywania tych wniosków oraz zaleceń do terapii rodzinie - czyli kilku osobom jednocześnie - omawiane są w ostatniej, piątej części Wskazówek. 
Zawarte w dokumencie wskazania są próbą wsparcia psychologów praktyków w rozwiązywaniu dylematów, na jakie napotykają podczas pracy w tak złożonej sytuacji, jaką jest diagnozowanie par oraz rodzin.

\section{Literatura cytowana}

Chrząstowski, S. (2014). Wiara psychoterapeutów we własny obiektywizm, w doświadczenie kliniczne oraz wartość informacji zwrotnych - perspektywa psychologii społecznej i poznawczej. Psychoterapia, 3(170), 15-26.

Chrząstowski, S., de Barbaro, B. (2011). Postmodernistyczne inspiracje w psychoterapii. Kraków: UJ.

Dattilio F. M. (2013). Terapia poznawczo-behawioralna par i rodzin. Podręcznik dla klinicystów.

Kraków: Wydawnictwo Uniwersytetu Jagiellońskiego.

Fernández-Ballesteros, R., De Bruyn, E. E. J., Godoy, A., Hornke, L. F., Ter Laak, J., Vizcarro, C., Westhoff, K., et al. (2001). Guidelines for the Assessment Process (GAP): A proposal for discussion. European Journal of Psychological Assessment, 17(3), 187-200.

Kodeks Etyczny Psychoterapeutów (2015). Polskie Towarzystwo Psychoterapeutyczne, pobrane dnia 15.01.2019 roku ze strony:

http://www.sntr.org.pl/userfiles/file/Kodeks\%20etyczny\%20pschoterapeuty.pdf

Krishnamurthy, R., VandeCreek, L., Kaslow, N.J., Tazeau,Y.N., Mivelle, M.L., Kerns, R., Stegman, R., Suzuki, L., Benton, S.A. (2004). Achieving competency In psychological assessment: Directions for education and training. Journal of Cinical Psychology, 7, 725-739.

Paluchowski, J. W. (2010). Diagnoza oparta na dowodach empirycznych - czy potrzebny jest polski Buros? Roczniki Psychologiczne, 2010, 13(2), 7-27.

Paluchowski, J. W. (2015). Kompetencje diagnostyczne psychologów. [W:] M. Filipiak, W. J.

Paluchowski, B. Zalewski i M. Tarnowska (red.), Diagnoza psychologiczna: kompetencje i standardy. Wybrane zagadnienia (35-56). Warszawa: Pracownia Testów Psychologicznych PTP.

Paluchowski, J. W., Tarnowska, M., Filipiak, M., Zalewski, B. (2015). Standardy diagnozy psychologicznej. [W:] M. Filipiak, W. J. Paluchowski, B. Zalewski i M. Tarnowska (red.), Diagnoza psychologiczna: kompetencje i standardy. Wybrane zagadnienia (57-93). Warszawa: Pracownia Testów Psychologicznych PTP.

Stemplewska-Żakowicz, K. (2009). Diagnoza psychologiczna. Diagnozowanie jako kompetencja profesjonalna. Gdańsk: GWP.

Stemplewska-Żakowicz, K. (2005). O różnorodności form wywiadu oraz prób jej uporządkowania. W: K. Stemplewska-Żakowicz, K. Krejtz (red.), Wywiad psychologiczny. T. 1: Wywiad jako postepowanie badawcze (17-30). Warszawa: Pracownia Testów PTP.

Zalewski, B., Kamińska, A. (2015). Diagnoza osób starających się o otrzymanie statusu uchodźcy w Polsce. [W:] M. Fiipiak, W. J. Paluchowski, B. Zalewski i M. Tarnowska (red.), Diagnoza psychologiczna: kompetencje i standardy. Wybrane zagadnienia (231-342). Warszawa: Pracownia Testów Psychologicznych PTP. 
Załącznik

\section{Wskazówki realizacji standardów ogólnych prowadzenia procesu diagnostycznego $w$ diagnostyce par i rodzin do psychoterapii}

Wskazówki są rozszerzeniem dokumentu „Standardy prowadzenia procesu diagnostycznego". Dokument powstał we współpracy dwóch sekcji oraz został uchwalony w dniu 19 stycznia 2019 roku przez Walne Zebranie Ogólnopolskiej Sekcję Psychoterapii Polskiego Towarzystwa Psychologicznego oraz w dniu 5 lipca 2019 roku przez Zarząd Sekcji Naukowej Terapii Rodzin Polskiego Towarzystwa Psychiatrycznego. Dokument odnosi Standardy ogólne praktyki diagnozowania w obszarze par i rodzin do psychoterapii ${ }^{1}$.

Standardy ogólne zapisane są pogrubioną czcionką i oznaczone kolejnymi numerami, natomiast wskazówki realizacji w obszarze psychoterapii par i rodzin zapisane są czcionką niebieską.

W brzmieniu standardów ogólnych stosowane jest pojęcie ,psycholog”, natomiast we wskazówkach używane jest pojęcie ,psychoterapeuta”, ponieważ nie każdy psychoterapeuta pracujący z parami i rodzinami jest z wykształcenia psychologiem. Należy jednak podkreślić, że psychoterapeuta opiera swoją prace na teoriach psychoterapeutycznych, których podstawą jest specjalistyczna i stale weryfikowana metodami naukowymi wiedza psychologiczna.

\section{Konieczne warunki wstępne}

1.1 Psycholog podejmuje decyzje czy wykona usługę diagnostyczną w odpowiedzi na skierowane do niego zapotrzebowanie na tę usługę od klienta (tzn. osoby bezpośrednio zainteresowanej, osób trzecich lub instytucji).

Wskazówki realizacji standardu $1.1 \mathrm{w}$ obszarze diagnostyki par i rodzin:

Zapotrzebowanie na usługę $\mathrm{w}$ zakresie diagnozy pary i rodziny mogą zgłosić różne podmioty:

- dwie osoby (para) lub więcej (rodzina);

- jedna z osób wchodzących w skład rodziny lub pary;

${ }^{1}$ Wskazówki opracował Zespół Roboczy ds. Diagnostyki Par i Rodzin w składzie: Bartosz Zalewski (koordynator), Hanna Pinkowska-Zielińska, Bartosz Szymczyk, Joanna Krasuska i Maria Zapolska-Downar. Szczególny wkład w treść dokumentu jako reprezentant Zarządu Sekcji Naukowej Terapii Rodzin PTP miał Szymon Chrząstowski. 
- przedstawiciel instytucji (np. lekarz, pedagog szkolny, kurator rodzinny);

- kilka podmiotów jednocześnie (np. lekarz psychiatra opiekujący się dzieckiem oraz jeden z rodziców dziecka).

Jeżeli w zgłaszającej się rodzinie są osoby wyrażające niechęć do uczestniczenia w spotkaniach diagnostycznych, psychoterapeuta może podjąć się pracy z niepełnym systemem rodzinnym, pod warunkiem, że działanie takie jest zgodne ze stosowanym podejściem psychoterapeutycznym. Psychoterapeuta posiada umiejętności budowania kontaktu diagnostycznego także $\mathrm{z}$ osobami niezmotywowanymi do uczestniczenia $\mathrm{w}$ procesie diagnozy.

Na konsultacjach diagnostycznych nie zawsze pojawiają się wszyscy członkowie rodziny. Podejmując decyzję o tym czy prowadzić taką konsultację diagnosta powinien rozważyć:

- kontekst diagnozy - kto i z jakiego powodu zgłosił rodzinę na konsultację (np. zgłoszenie $\mathrm{z}$ instytucji $\mathrm{w}$ celu zatrzymania przemocy $\mathrm{w}$ rodzinie wobec dziecka lub samodzielne zgłoszenie rodziny związane $\mathrm{z}$ deklarowanymi problemami rodzinnymi);

- wstępne własne rozumienie motywacji rodziny do konsultacji (np. motywacja ta jest inna gdy z umówionej pary do prywatnego gabinetu przychodzi tylko jedna osoba, a inna gdy na zaproszenie lekarza przyjeżdża z daleka cała rodzina, ale bez jednej osoby z powodów medycznych).

Niemniej diagnosta dokłada starań by zawrzeć kontrakt na badania diagnostyczne z wszystkimi członkami rodziny, mieszkającymi razem. Inne postępowanie (np. zaproszenie innych osób, takich jak rozwiedziony drugi rodzic biologiczny, dziadkowie czy dzieci mieszkające poza rodziną) wymaga odrębnego uzasadnienia opartego w wiedzy psychologicznej, wynikającej ze stosowanego podejścia psychoterapeutycznego, w jakim prowadzona jest diagnoza. W przypadku niemożności spełnienia tego warunku psychoterapeuta zawiesza prowadzenie procesu diagnostycznego. Psychoterapeuta może przeprowadzić interwencję w postaci rozmowy z częścią rodziny lub z pojedynczą osobą, w celu zwiększenia możliwości pojawienia się pozostałych członków rodziny/pary.

Należy podkreślić, że proces diagnostyczny par i rodzin z założenia wykracza poza liczbę formalnych konsultacji diagnostycznych. Konsultacje kończą się diagnozą wstępną oraz decyzją o rozpoczęciu lub nie pracy psychoterapeutycznej z daną rodziną/parą. Jednakże jeżeli tak wskazuje teoria psychoterapeutyczna, będąca podstawą diagnozy rodziny/pary diagnoza głębszych mechanizmów psychologicznych może trwać także podczas pracy terapeutycznej. 
W kontekście psychoterapii postępowanie diagnostyczne z parą lub rodziną wymaga realizowania dwóch zadań jednocześnie: diagnozy mechanizmów psychopatologicznych oraz rozpoznawania motywacji rodziny lub pary do uczestniczenia $\mathrm{w}$ diagnozie $\mathrm{i}$ terapii. Odpowiedź na drugie pytanie może być formułowana wcześniej niż na pierwsze i diagności mogą od razu, w trakcie procesu diagnostycznego wprowadzać interwencje wspierające motywację rodziny lub pary.

Odstąpienie od podjęcia się realizacji zadania diagnostycznego wymaga od diagnosty szczególnej refleksji. W kontekście psychoterapii w szczególnych sytuacjach można odstąpić od podjęcia się procesu diagnozowania rodziny i zarekomendowania innych działań np. diagnozy indywidualnej wobec wybranych osób z rodziny.

\subsection{Psycholog podejmuje się wykonania usługi diagnostycznej tylko wtedy, kiedy możliwe jest udzielenie odpowiedzi na pytanie diagnostyczne na podstawie współczesnej psychologicznej wiedzy naukowej}

\section{Wskazówki realizacji standardu $1.2 \mathrm{w}$ obszarze diagnostyki par i rodzin:}

Sformułowanie pytania diagnostycznego jest szczególnie złożone w kontekście pracy z kilkoma osobami naraz (tzn. rodziną/parą). Każdy członek rodziny może zgłaszać własne, odmienne od pozostałych, pytania diagnostyczne. Psychoterapeuta dąży do takiego przeformułowania pytań, aby zgodzili się nań wszyscy członkowie pary lub rodziny. Psychoterapeuta dba szczególnie o to, aby odpowiedzi na pytania diagnostyczne poszukiwać w oparciu o współczesną wiedzę psychologiczną naukową oraz wywodzącą się z naukowo zweryfikowanych teorii psychoterapeutycznych.

Psychoterapeuta aktywnie informuje członków rodziny o tym, co może być przedmiotem rozpoznania w trakcie diagnozy, a co nie i rozważa z rodziną na ile gotowa jest podjąć się uczestnictwa $\mathrm{w}$ takim procesie diagnostycznym. Psychoterapeuta wskazuje także to, kto będzie diagnozowany (rodzina lub para, a nie pojedyncza osoba, np. tylko dziecko) i podejmuje się diagnozy dopiero wtedy, kiedy para lub rodzina zgodzi się na bycie diagnozowaną jako całość. Ze względu na jednoczesne prowadzenie diagnozy oraz zajmowanie się motywacją rodziny do uczestniczenia w spotkaniach psychoterapeuta może dokonywać interwencji zwiększających szanse wejścia rodziny w proces diagnostyczny.

\subsection{Psycholog podejmuje się realizacji usługi diagnostycznej wtedy, gdy posiada odpowiednią: wiedzę, umiejętności oraz postawę etyczną}

Wskazówka realizacji standardu 1.3 w obszarze diagnostyki par i rodzin: 
Prowadzenie $\mathrm{p} /$ procesu diagnozowania par i rodzin wymaga:

(a) profesjonalnej wiedzy dotyczącej funkcjonowania rodzin,

(b) umiejętności pracy z kilkoma osobami jednocześnie,

(c) specyficznych kompetencji etycznych ,dotyczących pracy z osobami połączonymi silnymi więzami uczuciowymi ${ }^{2}$.

Wiedza o funkcjonowaniu jednostek może wspomagać rozumienie zjawisk zachodzących w rodzinie lub parze (por. pkt 1.8 Standardów ogólnych). Jednocześnie psychoterapeuta poszukuje aktywnie wiedzy, pozwalającej mu lepiej rozumieć specyficzne zjawiska działające w rodzinach (np. takich, które wywodząc się z odmiennej kultury lub rodzin z jedną osobą z odmiennej kultury ${ }^{3}$, rodzin osób cierpiących na długoterminowe choroby fizyczne lub o podłożu psychicznym, i innych).

\section{$1.4 \mathrm{~W}$ razie potrzeby, psycholog kieruje osobę diagnozowaną i/lub zleceniodawcę do innego specjalisty lub podejmuje wspólpracę z innym specjalistą.}

\section{Wskazówki realizacji standardu $1.4 \mathrm{w}$ obszarze diagnostyki par i rodzin:}

Podejmując współpracę $\mathrm{z}$ innymi specjalistami zajmującymi się tą samą rodziną, psycholodzy powinni szczególnie dbać o jawność komunikacji - tzn. dla wszystkich członków rodziny powinno być jasne, jaki rodzaj informacji będzie przekazywany między różnymi specjalistami. Diagności zobowiązani są dochować zasady świadomej zgody uczestników badań diagnostycznych na przekazywanie informacji ich dotyczących.

We współpracy $\mathrm{z}$ innymi specjalistami diagnosta uważnie rozstrzyga czy sam fakt otrzymywania od nich dodatkowych informacji o diagnozowanej rodzinie nie zaburzy procesu diagnozy. Rozstrzygnięcia takie wynikać powinny z teorii psychoterapeutycznej, jakiej psychoterapeuta używa do diagnozy.

Kwestią szczególnie trudną jest próba zobowiązania diagnosty, przez jednego z członków rodziny, do utrzymywania w tajemnicy przed innymi jej członkami wybranych faktów (np. posiadania romansu przez ta osobę, własnego uzależnienia lub innych ważnych kwestii). Dotrzymywanie przez psychoterapeutę takiej tajemnicy może skutecznie paraliżować możliwość prowadzenia diagnozy z daną parą lub rodziną.

${ }^{2}$ Zasady etyczne specyficznej dla pracy z parami/rodzinami omawia znowelizowany Kodeks Etyczny Polskiego Towarzystwa Psychiatrycznego (data, punkty).

3 Osobnym i ważnym problemem jest diagnoza rodzin niemówiących językiem psychoterapeuty - wskazówki dotyczące pracy diagnostycznej z asystą tłumacza zawarte są 
W sytuacji, gdy pojawia się możliwość otrzymania dodatkowych informacji o diagnozowanej parze/rodzinie od innych specjalistów lub poszczególnych członków rodziny, diagnosta, kierując się wskazówkami podejścia psychoterapeutycznego, będącego podstawą konsultacji, każdorazowo rozważa czy istnieją szczególne powody, dla których powinien skorzystać z dodatkowych informacji spoza rodziny oraz jakie będą konsekwencje posiadania przez niego takiej wiedzy dla prowadzenia prawidłowego procesu diagnostycznego. Ponadto diagnosta podejmuje działania powstrzymujące inne osoby od przekazywania mu dodatkowych informacji o rodzinie.

$\mathrm{W}$ niektórych sytuacjach kwestie te rozwiązywane są systemowo (np. psychoterapeuta jest członkiem personelu oddziału psychiatrycznego, w ramach którego konsultuje rodzinę leczonego pacjenta/pacjentki). W innych przypadkach (np. kierowanie z konsultacji lub terapii indywidualnej do konsultacji pary lub rodziny) diagnosta powinien dokładać szczególnych starań, aby upewnić się, że informacje od terapeuty indywidualnego przekazywane są jedynie w takim zakresie, na jaki zgodził się pacjent/osoba badana.

\subsection{Psycholog realizuje proces diagnostyczny dbając o dobro osoby diagnozowanej.}

Wskazówki realizacji standardu $1.5 \mathrm{w}$ obszarze diagnostyki par i rodzin:

Specyfiką pracy z parami oraz rodzinami jest umiejętność dbania o dobro wszystkich uczestników spotkania, szczególnie w przypadku wzajemnych negatywnych nastawień członków rodziny wobec siebie. Psychoterapeuta podczas prowadzenia diagnozy realizuje dbanie o dobro rodziny poprzez:

- dbanie o dobro każdego z jej członków;

- utrzymywanie profesjonalnej postawy zrównoważonej neutralności wobec wszystkich członków rodziny;

- możliwie najpełniejsze rozumienie zjawisk zachodzących w rodzinie;

- komunikowanie swojego rozumienia rodzinie.

Diagnosta aktywnie przeciwdziała procesom obciążania za trudności rodziny lub pary jednego z jej członków, w tym szczególnie stygmatyzowania lub etykietowania wybranych osób oraz nie wchodzi w koalicje z jedną częścią rodziny lub jedną osoba w parze, przeciwko pozostałym członkom, lecz pracuje $\mathrm{z}$ rodziną/parą jako całością. W sytuacji występowania aktywnej przemocy w rodzinie psychoterapeuta nie podejmuje się prowadzenia diagnostyki rodziny lecz podejmuje interwencje w celu zatrzymania przemocy.

omówieniu realizacji standardów w diagnozie osób ubiegających się o nadanie statusu uchodźcy w Polsce (por. Zalewski i Kamińska, 2015). 
Dyskomfort klientów podczas konsultacji diagnostycznych rodziny i pary - w porównaniu $\mathrm{z}$ diagnozą indywidualną - może być związany $\mathrm{z}$ wieloma dodatkowymi czynnikami, takimi jak: słyszenie negatywnych opinii na swój temat od innych członków rodziny $\mathrm{w}$ obecności psychoterapeutów, prezentowanie innych członków w negatywnym świetle czy dostrzeganie różnic między członkami rodziny. Jedną z sytuacji powodujących dyskomfort jest nie podejmowanie przez psychoterapeutę diagnozowania (a tym bardziej zmieniania) pojedynczych członków rodziny na zlecenie pozostałych (np. diagnozowanie i „naprawianie” nastolatka na zlecenie rodziców; diagnozowanie jednego partnera w parze na zlecenie drugiego). Może się to wiązać z dużą frustracją niektórych uczestników diagnozy lub stać w sprzeczności z ich celami oraz nadziejami związanymi ze zgłoszeniem rodziny na konsultacje diagnostyczne w kontekście psychoterapii. Psychoterapeuta informuje uczestników diagnozy, że tego typu zlecenia nie będą przez niego przyjmowane, tak aby rodzina jako całość mogła podjąć świadomą decyzję o uczestnictwie w konsultacjach.

Zawieszanie procesu diagnostycznego i wprowadzanie interwencji psychoterapeutycznych może wynikać (a) z konieczności zatrzymania występującej w rodzinie przemocy lub (b) sytuacji, w której kontynuowanie diagnozy naruszałoby godność i dobro drugiej osoby. Zaniechanie koniecznych interwencji jest wówczas działaniem na szkodę rodziny. Po skutecznej interwencji diagnosta podejmuje starania w kierunku kontraktowania procesu diagnostycznego i podejmuje z rodziną refleksję nad celami i przedmiotem diagnozy. Celem takiego działanie jest uniknięcie zaniechania rozumienia psychologicznej sytuacji $\mathrm{w}$ rodzinie, która pojawiła się u psychoterapeuty.

\subsection{Psycholog podejmuje się realizacji usługi diagnostycznej tylko wówczas, gdy może ją wykonywać z poszanowaniem dóbr, autonomii i praw osoby diagnozowanej oraz osób trzecich.}

\section{Wskazówki realizacji standardu $1.6 \mathrm{w}$ obszarze diagnostyki par i rodzin:}

Kwestii poszanowania dóbr, autonomii i praw członków rodziny diagnosta poświęca szczególną uwagę w sytuacji, gdy w konsultacji biorą udział osoby trzecie (np. stażyści). Praca w zespole wymaga wypracowania i dbania o przestrzeganie standardów diagnozy przez wszystkich uczestników zespołu diagnostycznego - odpowiedzialny za ich wypracowanie oraz przestrzeganie jest psychoterapeuta (lub para psychoterapeutów) prowadzący spotkanie. Wszyscy członkowie poszerzonego zespołu diagnostycznego dbają o dobro członków diagnozowanej rodziny - w tym zachowanie tajemnicy zawodowej, intymności spotkania, itp. 
Dbanie o dobro, autonomię i prawa każdej z osób w rodzinach przeżywających trudności emocjonalne (np. silnie skonfliktowanych) wymaga szczególnych profesjonalnych kompetencji psychoterapeuty (patrz pkt 1.3). W przypadku niemożności prowadzenia konsultacji z poszanowaniem dóbr, autonomii i praw członków rodziny psychoterapeuta powinien zaprzestać prowadzenia konsultacji i podjąć interwencje przywracające możliwość diagnozowania - działania te mają prymat nad prowadzeniem diagnozy. Należy wskazać, że jest to sytuacja odmienna niż w przypadku diagnozy indywidualnej, gdzie nie przerywa się procesu diagnostycznego w sytuacji, gdy uczestnik diagnozy werbalnie atakuje osoby ze swojej rodziny, ponieważ nie są obecne na konsultacji.

\subsection{Psycholog diagnosta korzysta z superwizji (indywidualnej, grupowej, koleżeńskiej).}

Wskazówki realizacji standardu $1.7 \mathrm{w}$ obszarze diagnostyki par i rodzin:

Superwizor konsultujący proces diagnozy pary lub rodziny posiada wysoce specjalistyczną wiedzę z zakresu psychoterapii oraz diagnostyki par i rodzin, a w przypadku superwizowania psychoterapeutów pracujących $\mathrm{w}$ koterapii także $\mathrm{z}$ zakresu specyfiki procesów zachodzący w relacji koterapeutycznej oraz superwizji takich procesów.

W trakcie superwizji (szczególnie grupowej) psychoterapeuta dokonujący diagnozy oraz superwizor danej pracy diagnostycznej dbają o zasady tajemnicy zawodowej. Osoby znające członków rodziny $\mathrm{z}$ innego kontekstu (np. terapeuci indywidualni członków rodziny) powinny powstrzymać się od uczestnictwa $\mathrm{W}$ tej części grupowego spotkania superwizyjnego, na którym omawiana jest dana para/rodzina. Odstępstwo od tej zasady powinno być szczególnie umotywowane oraz rozważone przez uczestników danej superwizji (sytuacja taka to np. superwizja personelu oddziału psychiatrycznego, w którym konsultowane są także rodziny, a który pracuje zespołowo, w sytuacji kiedy rodziny są poinformowane o omawianiu pracy terapeutycznej na zebraniach klinicznych czy superwizjach).

\subsection{Jeżeli psycholog nie posiada umiejętności niezbędnych do tego, by uwzględnić indywidualną perspektywę osoby diagnozowanej (np. nigdy nie pracowal z osobą reprezentującą daną grupę spoleczną czy doświadczającą danego problemu), komunikuje ten fakt osobie diagnozowanej i/lub zleceniodawcy wraz $z$ informacją $o$ ewentualnej dostępności innych psychologów specjalizujących się w danym obszarze pracy.}

Wskazówka realizacji standardu 1.8 w obszarze diagnostyki par i rodzin: 
Jeśli członkiem rodziny jest osoba pochodząca z innej kultury lub nie znająca języka, w jakim prowadzone są konsultacje diagnostyczne, rolą psychoterapeuty jest zakomunikowanie rodzinie związanych $\mathrm{z}$ tym trudności oraz poszukiwanie wraz $\mathrm{z}$ uczestnikami spotkań diagnostycznych rozwiązań, umożliwiających wszystkim członkom rodziny prezentowanie własnej perspektywy na omawiane kwestie rodzinne.

\subsection{W przypadku braku możliwości skierowania osoby diagnozowanej i/lub zleceniodawców do ekspertów z określonego obszaru psychologicznej praktyki diagnostycznej, psycholog podejmuje się realizacji usługi diagnostycznej pod warunkiem, że aktywnie poszerza swoją wiedzę w tym zakresie oraz poddaje dany proces diagnostyczny superwizji.}

\subsection{Psycholog stara się rozpoznać występujące (oraz potencjalne) konflikty, w jakich} może się znaleźć podczas realizacji procesu diagnostycznego.

\section{Wskazówki realizacji standardu $1.10 \mathrm{w}$ obszarze diagnostyki par i rodzin:}

W omawianym obszarze pojawić się może konflikt dotyczący diagnozowania rodziny oraz diagnozowania jednostki $\mathrm{w}$ trakcie tej samej konsultacji oraz przez tego samego diagnostę. Psychoterapeuta prowadzi diagnozę zgodnie $\mathrm{z}$ wybraną teorią psychoterapeutyczną i zajmuje się tym konfliktem zgodnie z wiedzą wynikającą z tej teorii.

$\mathrm{Np}$. w podejściu poznawczo-behawioralnym psychoterapeuta prowadzi diagnozę rodziny / pary z wyraźnymi elementami diagnozy indywidualnej (naprzemiennie prowadząc wywiady z rodziną i osobno z poszczególnymi jej członkami; por. Dattillo, 2013); w podejściu systemowym diagnozowanie jednostki jest wplątane $w$ zależności rodzinne, takie jak tworzenie przez psychoterapeutę koalicji z niektórymi członkami rodziny, naruszanie postawy neutralności psychoterapeuty, itd. (por. Chrząstowski, 2014).

Jeżeli proces diagnostyczny oraz proces terapeutyczny prowadzą różni psychoterapeuci (lub inne zespoły psychoterapeutów) obie strony muszą uzgodnić wspólne rozumienie diagnozy oraz wynikających z niej zaleceń, szczególnie w sytuacji, gdy diagnoza oraz terapia oparte są na odmiennych teoriach psychoterapeutycznych. Brak takiego uzgodnienia może prowadzić do odrzucenia przez psychoterapeutę otrzymanej diagnozy, jako operującej nieznanymi mu pojęciami, proponującą nieznane mu interwencje lub oferujące rozumienie rodziny, z którym się nie zgadza.

Prowadząc proces diagnostyczny rodziny psychoterapeuta narażony jest na działanie różnych sił, które naruszać mogą jego neutralną pozycję (np. domaganie się opowiedzenia się 
po czyjejś stronie, rozstrzygnięcia sporu, legitymizowania perspektyw niektórych członków rodziny jako dominujących wobec innych, itp). Psychoterapeuta starannie dochowuje zasady neutralności w kontaktach $\mathrm{z}$ członkami rodziny oraz poddaje superwizji swoje działania w tym kontekście.

W sytuacji, kiedy między psychoterapeutą a członkami rodziny lub osobami z pary występują wyraźne różnice światopoglądowe, psychoterapeuta kieruje się wskazaniami teorii psychoterapeutycznej, która jest podstawą jego działań diagnostycznych. Psychoterapeuta posiada umiejętności radzenia sobie z powyższymi konfliktami, m.in. poprzez umiejętność korzystania z konsultacji i wsparcia zespołu klinicznego, do którego należy oraz korzystania z superwizji procesu diagnostycznego.

\subsection{Jeżeli konieczne warunki wstępne są spełnione (patrz punkty 1.1 - 1.10), psycholog zawiera pisemny lub ustny kontrakt na badanie diagnostyczne na podstawie świadomej zgody osoby diagnozowanej.}

\section{Wskazówki realizacji standardu $1.11 \mathrm{w}$ obszarze diagnostyki par i rodzin:}

Psychoterapeuta wyjaśnia specyfikę i ograniczenia procesu diagnostycznego rodzinie, w tym podkreśla, że diagnoza nie jest osądzaniem, a jej wynikiem nie będzie orzeczenie o winie lub niewinności oraz, że każda z osób w rodzinie ma równe prawo wypowiadać się na temat rodziny - uzyskanie na to zgody jest konieczne do rozpoczęcia procesu diagnozowania.

Kontrakt na badania diagnostyczne zawiera para lub odpowiednia część rodziny (rodzice lub rodzice i dorosłe dzieci). Natomiast świadomą zgodę udziela każda z osób w rodzinie ${ }^{4}$. Należy wskazać, że zgoda ta obejmuje diagnozę rodziny, a nie pojedynczych osób i wnioski diagnostyczne będą dotyczyły rodziny ${ }^{5}$. Proces diagnostyczny pary i rodziny może być o wiele dłuższy niż proces diagnozy indywidualnej.

4 Kwestie uzyskiwania świadomej zgody od dzieci omawiane będą w osobnym dokumencie, dotyczącym realizacji standardów diagnozy wobec dzieci i młodzieży.

${ }^{5}$ Chyba, że teoria psychoterapeutyczna wskazuje inaczej, jak w przypadku poznawczobehawioralnej psychoterapii par (Dattilio, 2013). 
1.12 Psycholog uzgadnia z osobą diagnozowaną i/lub zleceniodawcą (osobą/instytucją zlecającą wykonanie usługi diagnostycznej) zakres przekazywanych we wnioskach diagnostycznych informacji, co stanowi element kontraktu dotyczącego tego badania diagnostycznego.

\section{Planowanie procesu diagnostycznego}

\subsection{Psycholog potrafi wskazać obszary wiedzy naukowej, będące podstawą} formułowania odpowiedzi na pytanie diagnostyczne.

Wskazówki realizacji standardu $2.1 \mathrm{w}$ obszarze diagnostyki par i rodzin:

Diagności potrafią wskazać specjalistyczną i aktualną wiedzę z zakresu teorii psychoterapeutycznej, stosowanej w danym procesie diagnostycznym. Teoria ta powinna być oparta o psychologiczną wiedzę naukową, a skuteczność prowadzonej na jej podstawie psychoterapii weryfikowana za pomocą metod naukowych. W kontekście diagnozy pary/rodziny do psychoterapii psycholodzy zwracają uwagę na zjawiska zachodzące w sytuacji emocjonalnie angażującej jednostkę wobec innych osób (swojej rodziny oraz psychoterapeutów), a także dbają o to, aby posiadać wiedzę oraz wrażliwość etyczną pozwalającą opisać to, jak może przeżywać siebie każda z osób w rodzinie (rodzicie, dzieci, inni) w trakcie konsultacji diagnostycznej.

2.2 Psycholog potrafi wskazać, co należy badać, by móc formułować twierdzenia dotyczące konkretnego badanego zagadnienia.

Wskazówki realizacji standardu $2.2 \mathrm{w}$ obszarze diagnostyki par i rodzin:

Diagności posiadają wskazaną $\mathrm{w}$ punkcie 2.1. specjalistyczną wiedzę $\mathrm{z}$ zakresu funkcjonowania par i rodzin, a także świadomość wynikających z tej wiedzy zasad postępowania.

\subsection{Psycholog opracowuje strategię diagnozowania.}

Wskazówki realizacji standardu $1.3 \mathrm{w}$ obszarze diagnostyki par i rodzin:

Podczas konsultacji diagnostycznych pary i rodziny wywierają zazwyczaj silny nacisk emocjonalny na diagnostę. Psychoterapeuta dokłada starań, aby być świadomym zarówno siły jak i charakteru tego wpływu na jego postępowanie, w tym szczególnie na 
zniekształcenia poznawcze pojawiające się podczas formułowania hipotez diagnostycznych. Ponadto psychoterapeuta dokłada starań, aby utrzymywać postawę neutralności w relacji z rodziną. Neutralność jest elementem strategii diagnozowania, ponieważ dzięki niej diagności mogą otrzymywać istotne informacje od wszystkich członków rodziny.

Przykładowe strategie wspierające neutralność diagnosty; prowadzenie procesu diagnostycznego przez dwie osoby (koterapia), świadomość oddziałujących na proces zbierania informacji oraz formułowania wniosków diagnostycznych zniekształceń poznawczych (por. Stemplewska-Żakowicz, 2009; Chrząstowski, 2014), aktywne ustalanie z osobami trzecimi zakresu dodatkowych informacji o rodzinie spoza konsultacji oraz dbałość o poprawność metodologiczną badania w kontekście kontaktu z wieloma osobami na konsultacji, a także przed i po niej.

\subsection{Psycholog ocenia związek zbieranych danych z konkretnym pytaniem diagnostycznym oraz przyjętym celem postępowania diagnostycznego.}

Wskazówki realizacji standardu $2.4 \mathrm{w}$ obszarze diagnostyki par i rodzin:

Cel badania może być odmienny dla psychoterapeuty oraz dla rodziny, a także odmienny dla każdego z członków rodziny (por. pkt. 1.1 i 1.2). Związek między działaniami psychoterapeutów i celami konsultacji diagnostycznych może być niejasny dla różnych uczestników konsultacji i powinien być na bieżąco wyjaśniany. Diagności powinni szczególnie dbać o budowanie i podtrzymywanie sojuszu diagnostycznego (por. Stemplewska-Żakowicz, 2009; Chrząstowski, 2014).

\subsection{Psycholog używa wyłącznie narzędzi diagnostycznych, które mają podstawy naukowe w zakresie danego obszaru diagnostyki.}

Wskazówki realizacji standardu $2.5 \mathrm{w}$ obszarze diagnostyki par i rodzin: Należy podkreślić konieczność silnego osadzenia stosowanych metod diagnostycznych w wybranej teorii psychoterapeutycznej, zarówno w przypadku metod ilościowych, jakościowych jak i obserwacji. 
2.6 Dobierając narzędzia, psycholog uwzględnia indywidualne właściwości uczestnika badania.

2.7 Dobierając standardowe narzędzia, psycholog uwzględnia ich właściwości psychometryczne.

2.8 Psycholog używa narzędzi z poszanowaniem osobistego i materialnego prawa autorskiego.

\subsection{Psycholog używa aktualnych wersji narzędzi diagnostycznych.}

\section{Badanie}

3.1 Psycholog prowadzi badania wylącznie w standardowych warunkach, umożliwiających porównywanie uzyskiwanych wyników

Wskazówki realizacji standardu $3.1 \mathrm{w}$ obszarze diagnostyki par i rodzin:

Jeżeli badanie rodziny obejmuje stosowanie obserwacji $\mathrm{w}$ warunkach naturalnych (w miejscu zamieszkania rodziny), rzetelność tej metody musi być oparta o jej osadzenie w stosowanej $\mathrm{w}$ danym procesie diagnostycznym teorii psychoterapeutycznej oraz prawidłowo zbudowanych wskaźnikach (por. pkt. 2.2 i 2.3; Stemplewska-Żakowicz, 2005).

\subsection{Psycholog zachowuje wlaściwą z punktu widzenia kodeksu etyki zawodowej} psychologa postawę wobec osoby uczestniczącej w badaniu.

Wskazówki realizacji standardu $3.2 \mathrm{w}$ obszarze diagnostyki par i rodzin:

Pytając o problemy rodziny diagnosta nieuchronnie i automatycznie prowokuje wzajemne narzekania, oskarżenia oraz ataki, w związku z tym w rodzinną konsultację diagnostyczną immanentnie wpisane jest ryzyko wzajemnego naruszania godności przez osoby, które zgłosiły się na konsultację. Diagnosta powinien aktywnie minimalizować ilość i natężenie tych ataków lub innych działań naruszających godność uczestników diagnozy; np. poprzez dbanie o to, by każdy uczestnik spotkania mógł wyrazić swoje zdanie na omawiany temat, by każda osoba mogła wypowiedzieć się w kontekście ataku na siebie, ale także 36 
poprzez definiowanie zasad komunikacji na spotkaniu, zatrzymywanie ataków, przeciwdziałanie przemocy oraz inne sposoby, będące elementem umiejętności praktycznych psychoterapeutów (por. pkt. 1.3).

Ujawnianie informacji o innych osobach w ich obecności może naruszać godność uczestników spotkania, w tym szczególnie ujawnianie informacji bez zgody drugiej osoby (np. dziecko opowiada o kłótniach rodziców, choć nie wyrazili na to zgody). Psychoterapeuta rozważa na bieżąco na ile ujawniane informacje mogę uderzać w godność uczestników oraz zawsze umożliwia omawianej osobie ustosunkowanie się do ujawnionych bez jej zgody treści. Psychoterapeuta podczas prowadzenia diagnozy bierze pod uwagę rozkład siły w rodzinie i jest świadomy sytuacji emocjonalnej osób o niższej pozycji w rodzinie; może np. uznać, że w danej rodzinie należy zatrzymywać rodzica, ujawniającego intymne sekrety dziecka niż dziecko ujawniające konflikty małżeńskie.

Psychoterapeuta powinien być świadomy konfliktu pomiędzy poszanowaniem sposobu funkcjonowania rodziny - w tym używanego przez nią języka, który może zawierać elementy wzajemnej dewaluacji, przypisywania sobie przez członków pary poniżających cech, itp. - a modyfikowaniem tego języka bez zgody rodziny (np. poprzez zatrzymywanie atakujących wypowiedzi jednego z jej członków, choć pozostali członkowie rodziny akceptują ten sposób wypowiadania się). Należy wskazać, że samo działanie profesjonalnie wyszkolonego diagnosty jest pro-godnościowe, a jego obecność amortyzuje ataki wewnątrz rodziny. Diagnosta powinien nieustannie używać interwencji, w które wpisane jest poszanowanie przeżyć każdej $\mathrm{z}$ osób $\mathrm{w}$ rodzinie. Interwencje takie to $\mathrm{np}$. niezgoda psychoterapeuty na pewne sposoby uwłaczającego opisywania członka rodziny przy jednoczesnym stałym zachęcaniu rodziny do dalszej rozmowy oraz proponowanie zastępowania uwłaczających określeń innymi. Jednocześnie rozważając ów konflikt diagnosta odnosi się do zasad zawartych w kodeksie etycznych psychoterapeuty, opisującego działania wobec par i rodzin ${ }^{6}$.

Właściwemu zachowywaniu etycznej postawy przez psychoterapeuty silnie sprzyja budowanie przez niego wysokiej jakości przymierza diagnostycznego z rodziną.

\subsection{Psycholog jest odpowiedzialny za kontrolowanie i minimalizowanie czynników zakłócających wynikających z jego interakcji z osobą diagnozowaną.}

Wskazówki realizacji standardu 3.3 w obszarze diagnostyki par i rodzin:

\footnotetext{
${ }^{6}$ Polskie Towarzystwo Psychiatryczne, Kodeks zasad etycznych psychoterapeuty, dostępny na: http://psychoterapia-ptp.pl/wp-content/uploads/2014/05/KodeksEtyczny_projekt.pdf
} 
W proces diagnostyczny pary lub rodziny wpisane są czynniki zakłócające, wynikające z wielu możliwych relacji, zachodzących między członkami rodziny a diagnostami. Diagnosta działa na rzecz minimalizowania czynników zakłócających zgodnie ze wskazówkami stosowanej w procesie diagnostycznym teorii psychoterapeutycznej; np. poprzez stosowanie specyficznych zasad prowadzenia konsultacji, takich jak rozpoczynanie spotkania tylko w obecności wszystkich członków rodziny, przerywanie rozmowy na czas, gdy jedna z osób opuszcza pomieszczenie, omówienie zasad kontaktu diagnosty i rodziny poza czasem konsultacji, i innych.

\section{Integracja danych}

\subsection{Psycholog integruje uzyskane w badaniu dane ilościowe oraz jakościowe w kontekście formułowania odpowiedzi na pytanie diagnostyczne}

Wskazówki realizacji standardu $4.1 \mathrm{w}$ obszarze diagnostyki par i rodzin:

W sytuacji, kiedy ten sam zespół diagnostyczny prowadzi jednocześnie proces diagnostyczny dziecka oraz rodziny, psychoterapeuta powinien zdecydować się na jedną z dwóch strategii badawczych:

- Strategia 1: proces diagnostyczny prowadzony jest dwutorowo, odrębnie dla dziecka i dla rodziny, a nadrzędnym celem diagnozy jest poszukiwanie odpowiedzi na pytanie o optymalne działania, jakie należy podjąć wobec danej rodziny. Nadrzędny cel wymusza działanie oparte o wybrane podejście teoretyczne oraz taki dobór metod diagnostycznych, których wnioski można połączyć i w efekcie sformułować spójne zalecenia dla rodziny oraz dla dziecka (np. zalecenie zastosowania interwencji terapeutycznych wobec dziecka i wspomagającej interwencji wobec rodziców lub odwrotne: interwencji terapeutycznych wobec rodziców i wsparcia wobec dziecka).

- Strategia 2: prowadzenie dwóch równoległych, ale odrębnych od siebie procesów diagnostycznych, przy wykorzystaniu dwóch różnych podejść teoretycznych oraz różnych metod diagnostycznych, a następnie formułowanie wniosków oraz rekomendacji osobno w każdym z prowadzonych procesów diagnostycznych. W przypadku pojawienia się sprzecznych wniosków lub rekomendacji, należy te sprzeczności poddać superwizji lub innym formom konsultacji, takim jak superwizja koleżeńska czy zebranie kliniczne zespołu terapeutycznego. W 
przypadku wybrania tej strategii wyzwaniem dla psychoterapeuty jest pozostawaniem neutralnym (np. diagnozując dziecko może emocjonalnie bardziej „pozostawać przy nim” i w ten sposób oddalać się od jego rodziców, co zaburza utrzymywanie pozycji neutralności podczas diagnozowania rodziny jako całości). Psychoterapeuta powinien szczególnie monitorować to, czy jest neutralny podczas konsultacji oraz superwizować kwestię swojej neutralności.

4.2 W odniesieniu do standardowych narzędzi diagnostycznych, psycholog bierze pod uwagę ich właściwości psychometryczne i adekwatnie do ich poziomu ocenia stopień zaufania, z jakim może odnosić się do uzyskanych wyników. W odniesieniu do wywiadu i obserwacji ocenia ich poprawność metodologiczną i na tej podstawie stopień zaufania, z jakim może odnosić się do uzyskanych wyników.

Wskazówki realizacji standardu $4.2 \mathrm{w}$ obszarze diagnostyki par i rodzin:

Prowadzenie procesu diagnostycznego przez więcej niż jedną osobę - w koterapii lub z zespołem diagnostycznym - wspiera metodologiczną refleksję nad jakością zebranego materiału, pod warunkiem, że diagności rozpoczną analizę zebranego materiału od analizy sposobu jego zbierania (tzn. oceny warunków prowadzenia wywiadu lub obserwacji).

4.3 Wszędzie tam, gdzie w toku badania wystąpiły zakłócenia w stosunku do warunków standardowych, psycholog uwzględnia możliwy wpływ tych zakłóceń na wynik badania i adekwatnie modyfikuje stopień zaufania, z jakim może odnosić się do uzyskanego wyniku.

\section{Komunikowanie efektów i dokumentowanie procesu diagnozy}

\subsection{Psycholog komunikuje wnioski diagnostyczne zgodnie z zawartym wcześniej kontraktem na badanie diagnostyczne.}

Wskazówki realizacji standardu $5.1 \mathrm{w}$ obszarze diagnostyki par i rodzin:

Informacje zwrotne dotyczące diagnozy udzielane są zleceniodawcy diagnozy oraz wszystkim uczestnikom procesu diagnostycznego. 
5.2 Psycholog przekazuje informacje o efektach procesu diagnozy w sposób dopasowany do odbiorcy.

5.3 Psycholog podejmuje się przeprowadzenia procesu diagnostycznego wyłącznie wtedy, gdy zapewnione są warunki właściwego przechowywania dokumentacji związanej z prowadzonymi działaniami.

5.4 Przekazywanie pełnej informacji dotyczącej procesu diagnozy odbywa się tylko wówczas, gdy jej odbiorcą jest upoważniony przez osobę diagnozowaną psycholog.

Wskazówki realizacji standardu $5.4 \mathrm{w}$ obszarze diagnostyki par i rodzin:

Psychoterapeuta może przekazywać wnioski diagnostyczne dotyczące rodziny innemu terapeucie (np. indywidualnemu terapeucie dziecka) wyłącznie przy zgodzie wszystkich dorosłych osób w rodzinie lub obojga opiekunów prawnych dziecka. W instytucjach, które pracują zespołowo (np. oddziały psychiatryczne), informacja przekazana jednemu członkowi zespołu może być przekazana wszystkim pozostałym członkom zespołu o ile rodzina została wcześniej poinformowana o takiej zasadzie, panującej w danej placówce.

W przypadku konsultacji pary do psychoterapii wyniki badania diagnosta może przekazać innemu psychoterapeucie (np. terapeucie indywidualnemu jednej z osób) wyłącznie przy zgodzie obojga osób z pary - niezgoda jednej z osób wyklucza ujawnianie jakichkolwiek informacji. Przekazywanie takich wniosków to sytuacja wyjątkowa i wymaga od diagnostów szczególnego namysłu, w którym wezmą oni pod uwagę dobro pary oraz wskazania teorii psychoterapeutycznej, wykorzystanej do diagnozy danej pary. Np. należy rozważyć czy informacje przekazane terapeucie indywidualnemu jednej osoby o jej partnerze będą sprzyjały pracy terapeutycznej pary czy ją utrudniały.

\subsection{Przekazywanie informacji w formie pisemnej odbywa się w sposób zapewniający jej} poufność.

Za każdym razem przy przekazywaniu informacji osobom trzecim, priorytetem dla diagnostów jest ochrona tajemnicy zawodowej. Należy pamiętać, że udzielenie informacji o rodzinie jest zawsze udzieleniem informacji o udziale $w$ tej rodzinie wszystkich jej członków, na co trzeba mieć zgodę każdego członka rodziny. 